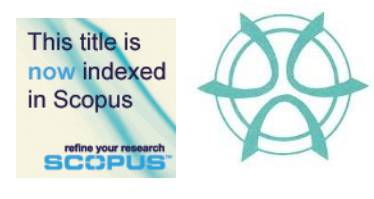

PLANNING MALAYSIA:

Journal of the Malaysian Institute of Planners

Volume XII (2014), Page 35 - 58

\title{
DISASTER RISK REDUCTION IN MALAYSIAN URBAN PLANNING
}

\author{
Intan Afida Mohamad Amin ${ }^{1}$ \& Halimaton Saadiah Hashim ${ }^{2}$ \\ ${ }^{1 \& 2}$ Institute for Environment and Development (LESTARI) \\ UNIVERSITI KEBANGSAAN MALAYSIA
}

\begin{abstract}
Disaster risk reduction (DRR) has become one of the main agenda at the global level. This is reflected in the 'Hyogo Framework for Action (20052015) Building the Resilience of Nations and Communities to Disasters' where one of the priority actions that has been agreed is to reduce the risk factors that can induce disasters. In addition, consensus was obtained during the United Nations Conference on Sustainable Development which was held in 2012 better known as Rio+20 where disaster risk reduction, resilience and risk resulting from climate change should be taken into account in urban planning. Strengthening the instruments for the implementation of disaster risk reduction and risk assessment is needed to ensure that more sustainable urban planning can be implemented in order to accommodate rapid development that goes hand in hand with rapid urban population growth in the future. This research explores the needs for disaster risk reduction in Malaysian urban planning and also explores the roles of urban planners in disaster risk reduction. Further, this study will briefly discuss on preliminary review on disaster risk reduction agendas that has been incorporated in five stages of development plans and document in Malaysian urban planning practice namely the National Physical Plan (NPP), the State Structure Plan (SSP), the Local Plan (LP), the Special Area Plan (SAP) and the Development Proposal Report (DPR).
\end{abstract}

Keyword: Disaster risk reduction, urban planning, urban planners

\footnotetext{
${ }^{1} \mathrm{PhD}$ student at the Institute for Environment and Development (LESTARI), Universiti Kebangsaan Malaysia, Bangi.Email: shmal.phd@gmail.com

${ }^{2}$ Senior Fellow at the Institute for Environment and Development (LESTARI), Universiti Kebangsaan Malaysia, Bangi. Email: halimaton.s.hashim@gmail.com.
} 
Intan Afida Mohamad Amin \& Halimaton Saadiah Hashim

Disaster Risk Reduction in Malaysian Urban Planning

\section{INTRODUCTION}

Impacts of disasters have been much discussed since the early development years, particularly after the industrial revolution in Europe. Demand for land for daily uses such as for housing, public amenities, utilities and businesses in urban areas has resulted in the use of areas which are exposed to danger like flood prone areas (Bosher et al.2008). Pelling (2006) notes that rapid urban development and ineffective urban governance have exposed a large number of the world's urban population to risks and hazards of disasters.

Any economic, social and environmental crisis will slow down the process of planned developments and thus affects current and future developments. The United Nations Human Settlement Programme (UNHSP) (2007) has pointed out that disasters can increase the negative effects of any development as they will prevent individuals, families, communities and nations from progressing. The losses due to the disasters in less developed and developing countries are increasing each year. This is because most of the infrastructure and other physical assets in these countries are more concentrated in one area and made them vulnerable to the disaster risks (The International Federation of Red Cross and Red Crescent Societies, 2006).

The importance of the application of disaster risk management and disaster risk reduction in urban planning can be seen in the early days from the United Nations agreements and declarations namely The Declaration of The Yokohama Strategy and Plan of Action for a Safer World in 1984, followed by the International Decade for Natural Disaster Reduction in 1990 (Montoya, 2004), the Habitat Agenda in 1996, The Declaration on Cities and Other Human Settlements in the New Millennium in 2001, The Hyogo Framework for Action 2005-2015 in 2005 and the latest was The Future We Want (Rio+20) in 2012. All agreements and declarations have urged and encouraged the international community to improve the prevention, preparedness, reduction and response aspects in order to reduce vulnerability of human settlements to natural disasters or man-made disasters as well as adoption of the post development programmes effectively.

In 2005, Malaysia is among 168 countries signed The Hyogo Framework for Action 2005-2015. This framework specifically calls upon all international players to integrate disaster risk management and disaster risk reduction into their country development framework (Benson \& Twigg, 2007) and especially in urban planning (Bosher et al., 2007; United Nations International Strategy for Disaster Reduction (UNISDR), 2005). There are five priorities that need to be addressed by all members namely: (1) ensure 
PLANNING MALAYSIA

Journal of the Malaysia Institute of Planners (2014)

that disaster risk reduction is a national and local priority with a strong institutional basis for implementation; (2) identify, assess and monitor disaster risks and enhance early warning; (3) use knowledge, innovation, research and education to build a culture of safety and resilience at all levels; (4) reduce the underlying risk factors; and (5) strengthen disaster preparedness for effective response at all levels (United Nations International Strategy for Disaster Reduction (UNISDR), 2005).

Malaysia has implemented The Hyogo Framework for Action through the existing National Security Council Directive No. 20. The Directive No.20 has been prepared by The National Security Council of Malaysia in 1997. Since then, this directive has been acting as the main reference for disaster management in Malaysia. The responsibilities and functions of related agencies for emergency management have been established to ensure all activities related to preparedness, prevention, response and recovery will be properly operated. The National Security Council of Malaysia has been acted as a coordinator for the implementation of The Hyogo Framework for Action in the country (National Security Council of Malaysia, 2011).

Since 2005, Malaysia is being very committed on the disaster management and disaster risk reduction and continuously supports the efforts towards implementing all five priorities areas as been stated in The Hyogo Framework for Action. Every two years, a review will be sent out to the United Nations Strategy for Disaster Reduction (UNISDR) to acknowledge the on-going actions taken by Malaysia regarding all the priorities in The Hyogo Framework for Action (National Security Council of Malaysia, 2011).

In urban planning, the implementation of Hyogo Framework for Action can be seen through various continuous efforts done by professionals in this area. Whether the efforts came from the local planning authorities, Town and Country Planning Departments or the private planning consultants, they all have the same objective in mind which is to ensure the urban planning practices in Malaysia will incorporates the disaster risk reduction agenda. Urban planners have the capability and authority to integrate disaster risk reduction agenda into their respective urban planning practices. A lot of efforts has been done by the urban planners in order to make sure they can implement the disaster risk reduction efforts through their urban planning practices such as through legislations and regulations and through various urban planning guidelines and manuals. 
Intan Afida Mohamad Amin \& Halimaton Saadiah Hashim

Disaster Risk Reduction in Malaysian Urban Planning

This research will explore the needs for disaster risk reduction in Malaysian urban planning and also explores the roles of urban planners in disaster risk reduction. Further, this study will briefly discuss on preliminary review on disaster risk reduction agenda that has been incorporated in five stages of development plans and document in Malaysian urban planning practice namely the National Physical Plan (NPP), the State Structure Plan (SSP), the Local Plan (LP), the Special Area Plan (SAP) and the Development Proposal Report (DPR) to get the idea on the implementation of disaster risk reduction in Malaysian urban planning practices.

\section{THE NEEDS FOR DISASTER RISK REDUCTION IN MALAYSIAN URBAN PLANNING}

Hazards and disasters are a threat to sustainable development. Integration of urban planning and disaster risk reduction is seen as an excellent effort towards sustainability (Mileti, 2002). Planning and building an environment that is able to deal with the potential effects of a disaster requires a deep understanding of specific knowledge on how to prevent and mitigate the impacts of disasters (Hamelin \& Hauke, 2005; Bosher et al. 2007). All parties responsible for urban planning, urban design and construction need to take into account all types of current and potential threats in their respective professional activities effectively (Bosher et al. 2007; Bosher \& Dainty, 2011).The agenda of resilience built environment should be integrated in the overall development framework from the very early stage of the construction and planning processes (Benson \& Twigg, 2007; Bosher et al. 2007; Powell, 2009).

Haigh and Amaratunga (2010) point out that built environment are designed to fulfil human needs and values. The overall quality of the built environment that we live are depending on how well we can design and maintain each component according to the specific context given to us. The design between each component in the built environment will determine the vulnerability of people and property (Berke \& Steven 2009). The resilience of built environment can be increased by putting more focus on the characteristics of the built environment as disasters happens because of the intersection between hazards and built environment characteristics. Disaster risk reduction need to be implemented in all stages of the construction of the built environment to ensure the vulnerability can be managed effectively from the early stage of development. 
PLANNING MALAYSIA

Journal of the Malaysia Institute of Planners (2014)

Disaster risk reduction effort can be incorporated in urban planning by making changes to the concepts and current practices used by all parties involved. The main outcome of urban planning is no longer just only producing various plans for an area but at the same time needs to be able to give guarantees in terms of security and prosperity from the physical, economic and social aspects for an area. This can be achieved by integrating disaster risk reduction into the planning activities such as through building regulation and development control and also the construction processes (Ofori, 2008).

Wamsler (2004) found that urban planning can reduce the risk of disaster through good physical design. Wamsler (2004) also urged that there is a need and potential to overcome the consequences of the disaster by combining disaster risk reduction and urban planning initiatives particularly in the pre-disaster phase. The importance of the application of disaster risk reduction in urban planning in particular has been asserted again by Wamsler (2006) by stating that urban planning is an important element of resistance that can prevent disasters from happening through land use control.

Malaysia is having disasters such as floods, landslides, thunder storms and severe haze every year (National Security Council, 2011). Floods become the biggest threat to Malaysia as it affects a lot of people and caused a lot of monetary losses for more than 100 years (Centre for Research on the Epidemiology of Disasters, 2013). Various disasters occurs in the urban areas as in the rural areas in Malaysia.The location of city in hazard prone areas will expose population to various kind of hazards (United Nations for Development Programme, 2004). The characteristics of many Malaysian urban areas which built on the floodplains has exposed them to the risk of disaster (Department of Irrigation and Drainage of Malaysia, 2009).

The conversion of floodplains to the urban surfaces will increase the impervious areas and disrupt the hydrological processes in that area. Floodplains continuosly chosen by people as their sites for development because of the locational advantages for various urban uses (Burby \& French, 1981). The economic, social and environmental advantages that floodplains have to offer the population makes them very attractive for development. These are some attraction reasons for development in floodplains (1) the land is easy to develop as it relatively flat; (2) easy to construct infrastructures such as roads and railways; (3) fertile land; and (4) accessible for water supply, waste disposal, hydropower and river transport (Department of Irrigation and Drainage of Malaysia, 2009). 
Intan Afida Mohamad Amin \& Halimaton Saadiah Hashim

Disaster Risk Reduction in Malaysian Urban Planning

Besides floods, Malaysia also experienced landslide disaster occasionally in a year. This disaster occurs due to several reasons namely weather, geology structure, rainfall, runoff, seismic activity, design weakness, deforestation, hill denudation, land use unsuitability, less maintenance, less supervision and heavy vehicle tremor (Mohamed Jamil, 2008). The physical dimensions of the urban areas especially the urban settlements has increased the vulnerability towards disaster. According to Alarslan (2008), the risks of urban settlements can be determined by examining various physical dimensions factors namely the site of the settlement whether it is located at the coastal, hillside or floodplain area, the ground survey of the settlement in terms of soil types and groundwater level, the planning standards of the settlement, land use, population density, population profile, construction density and quality of the settlement, the quality of urban infrastructure and services and the economic profile of the settlement. The disruption of one urban settlement due to any disaster will cause disruption to other urban settlement as well as they are related to each other in terms of location and resources (Bosher et al., 2008).

Urban planning in Malaysia plays a significant role in reducing the disaster risks. All of these disaster risks can be reduced through effective and efficient urban planning practices taken by the government and the private sectors in Malaysia. For example, various initiatives has been taken by the Federal Town and Country Planning Department of Peninsular Malaysia (FTCPDPM) to incorporate disaster risk reduction agendas in urban planning practices in Malaysia such as preparation of various planning guidelines and manuals as the main reference for the urban planners in conducting their respectives practices effectively and mainstreaming disaster risk reduction agendas in development plans and document namely the National Physical Plan, the State Structure Plan, the Local Plan, the Special Area Plan and the Development Proposal Report. Besides that, the FTCPDPM has introduced Land Use Planning Appraisal for Risk Areas (LUPAr) to achieve safety and sustainability in land use planning with effective disaster mitigation strategies and to provide general guidelines for development control in hazard prone areas and to provide mitigation measures for the areas (Mohamed Jamil, 2008). 
The FTCPDPM also has undertaken many research regarding flood, landslide and forest fire. They have published many monograph on their research and one of them is the Monograph of Geohazard in Land Use Planning. This monograph focuses on five areas which are (1) geohazard factors; (2) development policies in disaster risk areas; (3) geohazard study in development plans; (4) geohazard assessment; and (5) Low Impact Development (LID) design proposal. Other than that, FTCPDPM and Malaysian Institute of Planner (MIP) occasionally organized seminars and dialogs between urban planners in the government and private sector to exchange thoughts and discuss issues related to the current Malaysian urban planning practices. This seminars and dialogs are intentionally organized to get feedback from the urban planners on disaster risk reduction initiatives that could be implemented to enhance the quality of urban planning practices in Malaysia.

Even though a lot of initiatives provided by both government and private sectors related to mainstreaming disaster risk reduction in urban planning practices in Malaysia, there are still some issues that need to be addressed by urban planning communities. The issues are (1) non compliance of development plans and planning guidelines at local level; (2) lack of data for detail assessment at local level which need cooperation from other technical agencies; (3) ineffective implementation of development policies occurs when state plans fail to harmonize with national objectives and when the plan exceeds the national target; (4) lack of support and full commitment from local, state and other relevant authorities; and (5) conformity of local plans with development policies outlined at Federal and State level (Mohamed Jamil, 2008). If all of these issues addressed wisely by the urban planning communities, it will guarantee the succesful of disaster risk reduction agenda in urban planning practices in Malaysia.

\section{THE ROLE OF URBAN PLANNERS IN DISASTER RISK REDUCTION}

Urban planners play a significant role in mainstreaming disaster risk reduction in development planning (United Nations International Strategy for Disaster Reduction, 2001). They are responsible to determine the potential level of exposure and vulnerability of people towards disaster (Esteban et al., 2011). Urban planners have to understand hazards in terms of its location, magnitude and frequency in order to help them plan effectively. Besides that, they have to consider site viability in terms of 
Intan Afida Mohamad Amin \& Halimaton Saadiah Hashim

Disaster Risk Reduction in Malaysian Urban Planning

location, density, type and design of development (Berke \& Smith, 2009) and determine whether re-siting of land uses is needed to reduce disaster risks. They also have to know how to use different features of topography and landscape in order to reduce the impact of disaster (Benson \& Twigg, 2007).

Urban planners need to be proactive and committed to build knowledge among developers regarding disaster risk reduction agendas. Some of the assistance that can be done by them are explaining related policies and regulations, clarifying issues of sustainability to be addressed, providing detail information regarding related developments and give relevant advices to developers on how to carry out their developments with disaster risk reduction in mind (Berke \& Stevens, 2008).Urban planners also have been given the power and authority by their respective Act to challenge proposed development that they think will contribute to the vulnerability of an area and community (Berke \& Smith, 2009).

Regardless of whether the urban planners are from the public or private sectors, they all have one thing in common. They are responsible to reduce and minimize various types of vulnerabilities (McEntire, 2001) whether it is physical, economic, social, political, institution and environmental vulnerabilities. Urban planners in public and private sectors have to work hand in hand to ensure they can create disaster resilience community and environment that can last longer without causing any major problem in the future (Nolon, 2006). Urban planners have to know how to use various tools provided by the government and authorities in order to mitigate the disasters (El-Masri and Tipple, 2002). Using appropriate policies, guidelines and regulations will help urban planners to promote disaster resilient development.

Jones et al. (2009) has outlined the roles of urban planners in every phase of disaster risk management including the disaster risk reduction phase also known as the mitigation phase. Urban planners have their own role in mitigation, preparedness, response and recovery phase (see Table 1).

The significant roles of urban planners in every phase in disaster risk management outlined in Table 1 shown that urban planners is one of many important profession in construction industry that have their own unique responsibilities in helping the local authorities and communities to achieve sustainable development for their respective areas. To ensure their roles and responsibilities can be carried out effectively, urban planners need to equip themselves with knowledge related to disaster risk reduction. They could acquire the disaster risk reduction knowledge to name a few from the formal 
learning in the university, training and courses organized by various agencies, peer experience exchange and other reading materials such as books, documents and etc. The future urban planners need to take disaster risk reduction seriously in their urban planning practices to ensure all development planned by them will lead to long term sustainable development.

\section{PRELIMINARY REVIEW ON DISASTER RISK REDUCTION IN MALAYSIAN URBAN PLANNING}

The disaster risk reduction agendas that need to be addressed by urban planners in preparation of development plans and document are set out in various guidelines and manuals prepared by the Federal Town and Country Planning Department of Peninsular Malaysia (FTCPDPM) and Malaysian Institute of Planners (MIP).

According to the Town and Country Planning Act (TCPA) 1976 (Act 172), there are four development plans that need to be prepared at different level of development planning which namely the National Physical Plan (NPP), the State Structure Plan (SSP), the Local Plan (LP) and the Special Area Plan (SAP). In addition to the four development plans there is another important document need to be prepared by urban planners to assist local authorities in decision making at site planning level, namely the Development Proposal Report (DPR). The DPR is prepared and submitted by urban planners to the local planning authority on behalf of the land owner or the developer for the purpose of getting a planning permission, called Kebenaran Merancang.

Disaster risk assessment which consists of hazard and vulnerability analysis will be conducted in the preparation of these five development plans and document to allow urban planners to understand the impacts of various risks to the community and the planned area. Preliminary review of various guidelines and manuals regarding the preparation of development plans and document at different planning level in Malaysia has been done to identify the disaster risk reduction agenda adopted in every development plans and document. The identifications of disaster risk reduction agendas adopted in every planning sector in these guidelines and manuals are using the hazard and vulnerability analysis criteria as in Table 2 and the findings are outlined in Table 3. 
Intan Afida Mohamad Amin \& Halimaton Saadiah Hashim

Disaster Risk Reduction in Malaysian Urban Planning

Table 8: Roles of Urban Planners in Each Phases of Disaster Risk Management

\begin{tabular}{|c|c|c|c|}
\hline Phase & Activity & $\begin{array}{l}\text { Activity } \\
\text { component }\end{array}$ & Roles of urban planners \\
\hline \multirow[t]{2}{*}{$\begin{array}{l}\text { Mitigatio } \\
n\end{array}$} & $\begin{array}{l}\text { Risk } \\
\text { assessment } \\
\text { and exposure } \\
\text { to danger }\end{array}$ & $\begin{array}{l}\text { Risk } \\
\text { assessment } \\
\text { and exposure } \\
\text { to danger }\end{array}$ & $\begin{array}{l}\text { - Estimate the exposure of people and } \\
\text { buildings towards disaster risks and } \\
\text { analyze the effectiveness of existing } \\
\text { regulations to mitigate disaster }\end{array}$ \\
\hline & $\begin{array}{l}\text { Disaster risk } \\
\text { reduction and } \\
\text { mitigation }\end{array}$ & $\begin{array}{l}\text { Disaster risk } \\
\text { reduction and } \\
\text { mitigation }\end{array}$ & $\begin{array}{l}\text { - Identify risks according to area, give } \\
\text { relevant advices on disaster risk } \\
\text { reduction and plan quality } \\
\text { development in the suitable location }\end{array}$ \\
\hline $\begin{array}{l}\text { Prepare } \\
\text { d-ness }\end{array}$ & $\begin{array}{l}\text { Disaster } \\
\text { preparedness } \\
\text { and pre- } \\
\text { disaster } \\
\text { planning }\end{array}$ & $\begin{array}{l}\text { Disaster } \\
\text { preparedness } \\
\text { and pre- } \\
\text { disaster } \\
\text { planning }\end{array}$ & $\begin{array}{l}\text { - Identify the settlement at risk and } \\
\text { give relevant advices on relocation } \\
\text { during and after disasters }\end{array}$ \\
\hline \multirow[t]{4}{*}{$\begin{array}{l}\text { Respons } \\
\text { e }\end{array}$} & \multirow[t]{4}{*}{$\begin{array}{l}\text { Emergency } \\
\text { relief }\end{array}$} & $\begin{array}{l}\text { Emergency } \\
\text { water supply } \\
\text { and sanitation }\end{array}$ & $\begin{array}{l}\text { - Estimate the demand for clean water } \\
\text { and the locations where it is needed }\end{array}$ \\
\hline & & $\begin{array}{l}\text { Logistical } \\
\text { planning }\end{array}$ & $\begin{array}{l}\text { - Evaluate local access and plan for } \\
\text { transportation and storage for } \\
\text { supplies and establish needs of } \\
\text { affected communities }\end{array}$ \\
\hline & & Relief shelters & $\begin{array}{l}\text { - Estimate the shelter demand in terms } \\
\text { of number, type and location }\end{array}$ \\
\hline & & $\begin{array}{l}\text { Project } \\
\text { planning and } \\
\text { management }\end{array}$ & $\begin{array}{l}\text { - Assess initial infrastructure recovery } \\
\text { requirements and liaise with all } \\
\text { stakeholders and communities to } \\
\text { establish feasible strategic plans for } \\
\text { the affected areas }\end{array}$ \\
\hline \multirow[t]{3}{*}{$\begin{array}{l}\text { Recover } \\
\mathrm{y}\end{array}$} & \multirow[t]{3}{*}{$\begin{array}{l}\text { Early } \\
\text { Recovery }\end{array}$} & $\begin{array}{l}\text { Physical } \\
\text { condition } \\
\text { surveys }\end{array}$ & $\begin{array}{l}\text { - Assess potential locations for interim } \\
\text { settlements, transitional dwellings } \\
\text { and important facilities by having } \\
\begin{array}{l}\text { consultation } \\
\text { stakeholders }\end{array}\end{array}$ \\
\hline & & $\begin{array}{l}\text { Compensation } \\
\text { packages }\end{array}$ & $\begin{array}{l}\text { - Give advice on strategic objectives of } \\
\text { compensation packages }\end{array}$ \\
\hline & & Rapid mapping & $\begin{array}{l}\text { - Work with surveyors to establish } \\
\text { proper maps that can provide the } \\
\text { estimation of the disaster impact on } \\
\text { land use, transport and access lines }\end{array}$ \\
\hline $\begin{array}{l}\text { Recover } \\
\text { y }\end{array}$ & $\begin{array}{l}\text { Early } \\
\text { Recovery }\end{array}$ & $\begin{array}{l}\text { Community } \\
\text { surveys } \\
\text { /resource } \\
\text { mapping }\end{array}$ & $\begin{array}{l}\text { - Provide information on population, } \\
\text { households, social and economic } \\
\text { activities and carry out additional } \\
\text { participatory surveys to get the }\end{array}$ \\
\hline
\end{tabular}


PLANNING MALAYSIA

Journal of the Malaysia Institute of Planners (2014)

communities aims

\begin{tabular}{|c|c|}
\hline g needs & $\begin{array}{l}\text { - Evaluate overall housing needs, } \\
\text { establish the type of infrastructure, } \\
\text { housing and land required for } \\
\text { transitional and permanent housing } \\
\text { and also consider layout design at the } \\
\text { settlement level }\end{array}$ \\
\hline $\begin{array}{l}\text { Lan } \\
\text { and }\end{array}$ & $\begin{array}{l}\text { - Advise on optimum locations for } \\
\text { transitional housing based on } \\
\text { economic, social and environmental } \\
\text { considerations and have consultations } \\
\text { with the communities and local } \\
\text { authorities regarding the exchange, } \\
\text { purchase and transfer of land }\end{array}$ \\
\hline $\begin{array}{l}\text { Phy } \\
\text { plan }\end{array}$ & $\begin{array}{l}\text { - Plan in terms of buildings locations, } \\
\text { key facilities, transport routes and } \\
\text { access }\end{array}$ \\
\hline $\begin{array}{l}\text { Infra } \\
\text { dem } \\
\text { air/re }\end{array}$ & $\begin{array}{l}\text { - Identify key infrastructure that need } \\
\text { priorities action }\end{array}$ \\
\hline $\begin{array}{l}\text { Tran } \\
\text { shelt }\end{array}$ & $\begin{array}{l}\text { - Draw and amend local planning } \\
\text { policies and guidelines to take into } \\
\text { account transitional housing } \\
\text { requirements and site planning to } \\
\text { ensure access to necessary facilities }\end{array}$ \\
\hline $\begin{array}{l}\text { Land } \\
\text { boundary/ } \\
\text { cadastral } \\
\text { survey }\end{array}$ & $\begin{array}{l}\text { - Give advice on physical planning to } \\
\text { the local authorities and communities }\end{array}$ \\
\hline $\begin{array}{l}\text { Project } \\
\text { planning and } \\
\text { management }\end{array}$ & $\begin{array}{l}\text { - Plan strategically for disaster affected } \\
\text { areas to ensure integrated delivery of } \\
\text { housing and services, coordinate } \\
\text { inputs from various professionals and } \\
\text { guide all stakeholders involved on } \\
\text { the implementations of codes of } \\
\text { standards and regulations related to } \\
\text { disaster risk reduction }\end{array}$ \\
\hline $\begin{array}{l}\text { Land } \\
\text { development } \\
\text { and landscape } \\
\text { design }\end{array}$ & $\begin{array}{l}\text { - Determine overall settlements } \\
\text { location, access routes and type of } \\
\text { infrastructures that need to be } \\
\text { reconstruct for that disaster affected } \\
\text { areas }\end{array}$ \\
\hline Hol & $\begin{array}{l}\text { - Allocate the number of dwe } \\
\text { needed in every settlement acc }\end{array}$ \\
\hline
\end{tabular}


Intan Afida Mohamad Amin \& Halimaton Saadiah Hashim

Disaster Risk Reduction in Malaysian Urban Planning

\section{to needs assessment}

Reconstruction regulations and

- Propose ways on how to monitor and enforce all regulations that have been codes established and give advice on longer term policies and plan development to support future risk reduction and efficient response to risks

Housing and - Manage and amend local planning building design policies and guidelines to take into account of new housing and site planning requirements

Housing and - Provide background information on building by laws, construction practices and construction compliance to the local communities advice

Infrastructure - Make sure that planned
planning and infrastructures meets the implementatio communities demand as well as the $\mathrm{n}$ regulation requirements imposed by the local authorities and also develop integrated spatial strategies and action plans for the implementation

Training $\quad$ Provide training in research and risk assessment to the communities so that when they design the new permanent settlements it will comply with the regulations and policies

\begin{tabular}{|c|c|}
\hline $\begin{array}{l}\text { Project } \\
\text { planning and } \\
\text { management }\end{array}$ & $\begin{array}{l}\text { - Provide strategic input and } \\
\text { consultation with communities and } \\
\text { local authorities in order to establish } \\
\text { projects aim and objectives at the } \\
\text { local level }\end{array}$ \\
\hline
\end{tabular}

Financial Provide background estimation on planning and funding required and give advice on management the future locally generated revenue to the local authorities and communities

Post Monitoring Periodically review the demand and reconstruction and evaluation capacity of infrastructures, review the development, disaster preparedness plans by having consultation with local communities review and ongoing risk and monitor the implementation and reduction compliance of regulations by the stakeholders involved in this activity

Project $\bullet$ Work with local communities to


PLANNING MALAYSIA

Journal of the Malaysia Institute of Planners (2014)

\begin{tabular}{ll}
$\begin{array}{l}\text { planning and } \\
\text { management }\end{array}$ & $\begin{array}{l}\text { review and renew plans for long term } \\
\text { sustainable human settlement } \\
\text { development }\end{array}$ \\
\hline $\begin{array}{l}\text { Cost- } \\
\text { effectiveness } \\
\text { and financial } \\
\text { advice }\end{array}$ & $\begin{array}{l}\text { Give advice on how to establish } \\
\text { disaster risk reduction regulations } \\
\text { that cost less to implement }\end{array}$ \\
\hline $\begin{array}{l}\text { Infrastructure } \\
\text { maintenance } \\
\text { advice }\end{array}$ & $\begin{array}{l}\text { - Raise awareness among general } \\
\text { public and enforcing the regulations } \\
\text { when necessary }\end{array}$ \\
\hline Retraining & $\begin{array}{l}\text { Provide training for the professionals } \\
\text { in local authorities regarding the risk } \\
\text { assessment so that they can plan their } \\
\text { development with disaster risk } \\
\text { reduction in mind }\end{array}$
\end{tabular}

Source: Jones et al, 2009

Table 9: Hazard and Vulnerability Analysis Criteria

\begin{tabular}{|c|c|c|c|}
\hline \multicolumn{2}{|c|}{ Type of analysis } & & Criteria \\
\hline \multicolumn{2}{|c|}{ Hazard analysis } & \multicolumn{2}{|c|}{$\begin{array}{l}\text { - What kind of hazard exists? } \\
\text { - What are the features of those hazards? } \\
\text { - What are the frequencies of those hazards? } \\
\text { - How many populations are within hazard prone areas? } \\
\text { - Where it might happen? } \\
\text { - What is the scale and trend of those hazards? } \\
\end{array}$} \\
\hline \multicolumn{2}{|c|}{$\begin{array}{l}\text { Vulnerability } \\
\text { analysis }\end{array}$} & \multicolumn{2}{|c|}{$\begin{array}{l}\text { - Who are the most vulnerable? } \\
\text { - Where are the most vulnerable? } \\
\text { - Why are they vulnerable? } \\
\text { - What makes them vulnerable? } \\
\text { - What assets are vulnerable? } \\
\text { - Tow will vulnerabilities alter? } \\
\end{array}$} \\
\hline \multicolumn{4}{|c|}{$\begin{array}{r}\text { Sources: Department for International Development, 2012; Jianping Yan, 2010; Jieh-Jiuh Wang, } \\
\text { 2012; United Nations Development Programme, } 2010\end{array}$} \\
\hline $\begin{array}{l}\text { Planning } \\
\text { level }\end{array}$ & $\begin{array}{l}\text { Development } \\
\text { plan }\end{array}$ & Sectors involved & $\begin{array}{c}\text { Disaster risk reduction agenda } \\
\text { adopted }\end{array}$ \\
\hline National & $\begin{array}{l}\text { National } \\
\text { Physical } \\
\text { Plan }\end{array}$ & $\begin{array}{l}\text { Physical } \\
\text { development and } \\
\text { urbanization }\end{array}$ & $\begin{array}{l}\text { - Provide a map that shows terrain } \\
\text { areas which are not suitable for } \\
\text { development } \\
\text { - Provide environmentally sensitive } \\
\text { area map showing the water } \\
\text { catchments, } \\
\text { forests, rice reserves areas, minerals }\end{array}$ \\
\hline
\end{tabular}


and marine park areas

- Map filtering needs to be assessed according to the evaluation of environmental

capacity

Agriculture $\quad$ Outline the spatial policies and
strategies that support the existing agricultural and forestry sectors policies and strategies to improve productivity while maintaining the quality of the environment and biological diversity

Urbanisation $•$ Define the limits of urban
development

Population, $\quad$ Formulate and analyse the profile of housing and the current population in terms of public facilities size, growth rate, distribution and density by state

- Provide the development policies and strategies of countries and territories

important public facilities according to their placement, location and level of use

Irrigation and - Identify the current capacity and
drainage maximum level of existing drainage system

- Make the projection of total capacity of liquid waste that will be generated for the proposed land use development

Sewerage $\quad$ Identify the current capacity and maximum level of existing sewerage system

Transportation - Evaluate the impact of land, air and sea transportation system on the development of the country, region and state

Environment and - Analyse and map out areas with natural resource mineral resources which need to be reserved, geo-hazard areas and areas with geological interests

- Identify environmental sensitive areas 
PLANNING MALAYSIA

Journal of the Malaysia Institute of Planners (2014)

\begin{tabular}{|c|c|c|c|}
\hline \multirow[t]{6}{*}{ State } & \multirow[t]{6}{*}{$\begin{array}{l}\text { Structure } \\
\text { Plan }\end{array}$} & $\begin{array}{l}\text { Population and } \\
\text { human resource } \\
\text { planning }\end{array}$ & $\begin{array}{l}\text { Analyse existing policies, } \\
\text { formulating population distribution } \\
\text { policies and } \\
\text { strategies based on the spatial } \\
\text { development of the state } \\
\text { - Provide population distribution plan }\end{array}$ \\
\hline & & $\begin{array}{l}\text { Land use and } \\
\text { physical }\end{array}$ & $\begin{array}{l}\text { - Review and analyse the topography } \\
\text { and geological structure of the area of } \\
\text { the } \\
\text { state to identify the constraints and } \\
\text { potential development } \\
\text { Formulate policies and state land } \\
\text { use spatial strategies towards } \\
\text { sustainable } \\
\text { development }\end{array}$ \\
\hline & & $\begin{array}{l}\text { Urban and rural } \\
\text { settlement }\end{array}$ & $\begin{array}{l}\text { - Determine the boundaries of the } \\
\text { development of the city } \\
\text { - Determine the needs of the green } \\
\text { belt between the urban and rural areas }\end{array}$ \\
\hline & & Housing & $\begin{array}{l}\text { - Review the requirements for the } \\
\text { provision of high, medium and low } \\
\text { density } \\
\text { housing }\end{array}$ \\
\hline & & $\begin{array}{l}\text { Drainage and } \\
\text { irrigation }\end{array}$ & $\begin{array}{l}\text { - Review the drainage system and } \\
\text { drainage network including its area } \\
\text { and } \\
\text { analyse the effectiveness and } \\
\text { capacities of existing systems } \\
\text { - Identify areas having problem with } \\
\text { flooding and flash floods }\end{array}$ \\
\hline & & $\begin{array}{l}\text { Environment and } \\
\text { natural resource } \\
\text { management }\end{array}$ & $\begin{array}{l}\text { - Identify environmental sensitive } \\
\text { areas } \\
\text { - Review of the environment } \\
\text { management system } \\
\text { - Examine conflicts of environment } \\
\text { and identify approaches to resolve } \\
\text { them }\end{array}$ \\
\hline \multirow[t]{2}{*}{ District } & \multirow[t]{2}{*}{ Local Plan } & $\begin{array}{l}\text { Physical and land } \\
\text { use characteristics }\end{array}$ & $\begin{array}{l}\text { - Analyse the topography, geology, } \\
\text { soils and hydrology of an area }\end{array}$ \\
\hline & & $\begin{array}{l}\text { City centre and } \\
\text { commercial }\end{array}$ & $\begin{array}{l}\text { - Analyse the level and intensity of } \\
\text { city centres development } \\
\text { - Review the requirements of } \\
\text { greenbelt to separate the city and } \\
\text { rural areas in } \\
\text { order to protect wildlife and other }\end{array}$ \\
\hline
\end{tabular}


Intan Afida Mohamad Amin \& Halimaton Saadiah Hashim

Disaster Risk Reduction in Malaysian Urban Planning

important function of ecology

$\begin{array}{ll}\text { Housing } & \text { Analyse the problems of housing } \\ & \text { estates such as squatters, } \\ & \text { environmental }\end{array}$

environmental

Public facilities $\quad$ An assessment of the facilities that need expansion, improvement or relocation.

Rural area $\quad$ Analyse the distribution of land use
development and physical condition of the settlement itself

\begin{tabular}{lllr}
\hline Industry & $\begin{array}{l}\text { Assessment of industrial waste } \\
\text { disposal system }\end{array}$ & \\
\hline $\begin{array}{l}\text { Population and } \\
\text { employment }\end{array}$ & $\begin{array}{l}\text { The distribution and current } \\
\text { population density and major } \\
\text { settlement blocks }\end{array}$ & & \\
&
\end{tabular}

Transportation - Analyse capacity, physical

and traffic

management condition, hierarchy, and reserve system

routes/roads in the main settlement

- Analyse the accident area and the black area

Drainage and $\quad$ Analyse the effectiveness and irrigation capacity of drainage and irrigation systems

- Analyse the natural drainage system in river basins

- Analyse the flood area and their causes as well as the number of people involved

- Analyse the ability of the retention and detention pond

Environment and - Identify areas that suffer from natural resource pollution, the level of pollution and management pollution

sources

- Identify location, the importance and the threat of environmental sensitive areas

- Analyse the carrying capacity

- Analyse the environmental sensitive areas 
PLANNING MALAYSIA

Journal of the Malaysia Institute of Planners (2014)

\begin{tabular}{|c|c|c|c|}
\hline & & & $\begin{array}{l}\text { - Identify issues, problems, potential } \\
\text { and constraints related to the area at } \\
\text { risk }\end{array}$ \\
\hline $\begin{array}{c}\text { Special } \\
\text { Area }\end{array}$ & $\begin{array}{l}\text { Special Area } \\
\text { Plan }\end{array}$ & $\begin{array}{l}\text { Type I } \\
\text { Redevelopment } \\
\text { of city centre }\end{array}$ & $\begin{array}{l}\text { - Analyse the physical issues and } \\
\text { social safety issues that lead to } \\
\text { redevelopment } \\
\text { - Analyse the potential and } \\
\text { constraints of the existing areas } \\
\text { - Traffic management relationship } \\
\text { with surrounding areas } \\
\text { - Social Impact Assessment (SIA) of } \\
\text { development }\end{array}$ \\
\hline \multirow{3}{*}{$\begin{array}{c}\text { Special } \\
\text { Area }\end{array}$} & \multirow{3}{*}{$\begin{array}{c}\text { Special Area } \\
\text { Plan }\end{array}$} & $\begin{array}{l}\text { Type II } \\
\text { Heritage interest } \\
\text { area }\end{array}$ & $\begin{array}{l}\text { - The aspects of the current situation } \\
\text { in terms of conditions and } \\
\text { maintenance of } \\
\text { the buildings } \\
\text { - Aspects of spaces in terms of } \\
\text { building conditions, environment } \\
\text { quality, traffic } \\
\text { conditions and economic and social } \\
\text { aspects } \\
\text { - Social Impact Assessment(SIA) of } \\
\text { development }\end{array}$ \\
\hline & & $\begin{array}{l}\text { Type III } \\
\text { Environmental } \\
\text { sensitive areas } \\
\text { Rank } 1 \text { and Rank } \\
2\end{array}$ & $\begin{array}{l}\text { - Identify the value of life support, } \\
\text { the threat and the need for } \\
\text { sustainability } \\
\text { - The impact of surrounding area } \\
\text { development } \\
\text { - Analyse the carrying } \\
\text { capacity/environmental impact } \\
\text { - Social Impact Assessment (SIA) of } \\
\text { development }\end{array}$ \\
\hline & & $\begin{array}{l}\text { Type IV } \\
\text { Special needs } \\
\text { area }\end{array}$ & $\begin{array}{l}\text { - Issues of physical, social and } \\
\text { economic lead to special actions in } \\
\text { the area } \\
\text { - Social Impact Assessment (SIA) of } \\
\text { development }\end{array}$ \\
\hline \multirow[t]{2}{*}{ Site } & \multirow{2}{*}{$\begin{array}{l}\text { Development } \\
\text { Proposal } \\
\text { Report }\end{array}$} & \multicolumn{2}{|c|}{ Analysis of existing site conditions } \\
\hline & & Existing land use & $\begin{array}{l}\text { - Description of the development of } \\
\text { the surrounding area that is } \\
\text { likely to receive/give impact on the } \\
\text { development on the site } \\
\text { - Description on analysis and site }\end{array}$ \\
\hline
\end{tabular}


Intan Afida Mohamad Amin \& Halimaton Saadiah Hashim

Disaster Risk Reduction in Malaysian Urban Planning

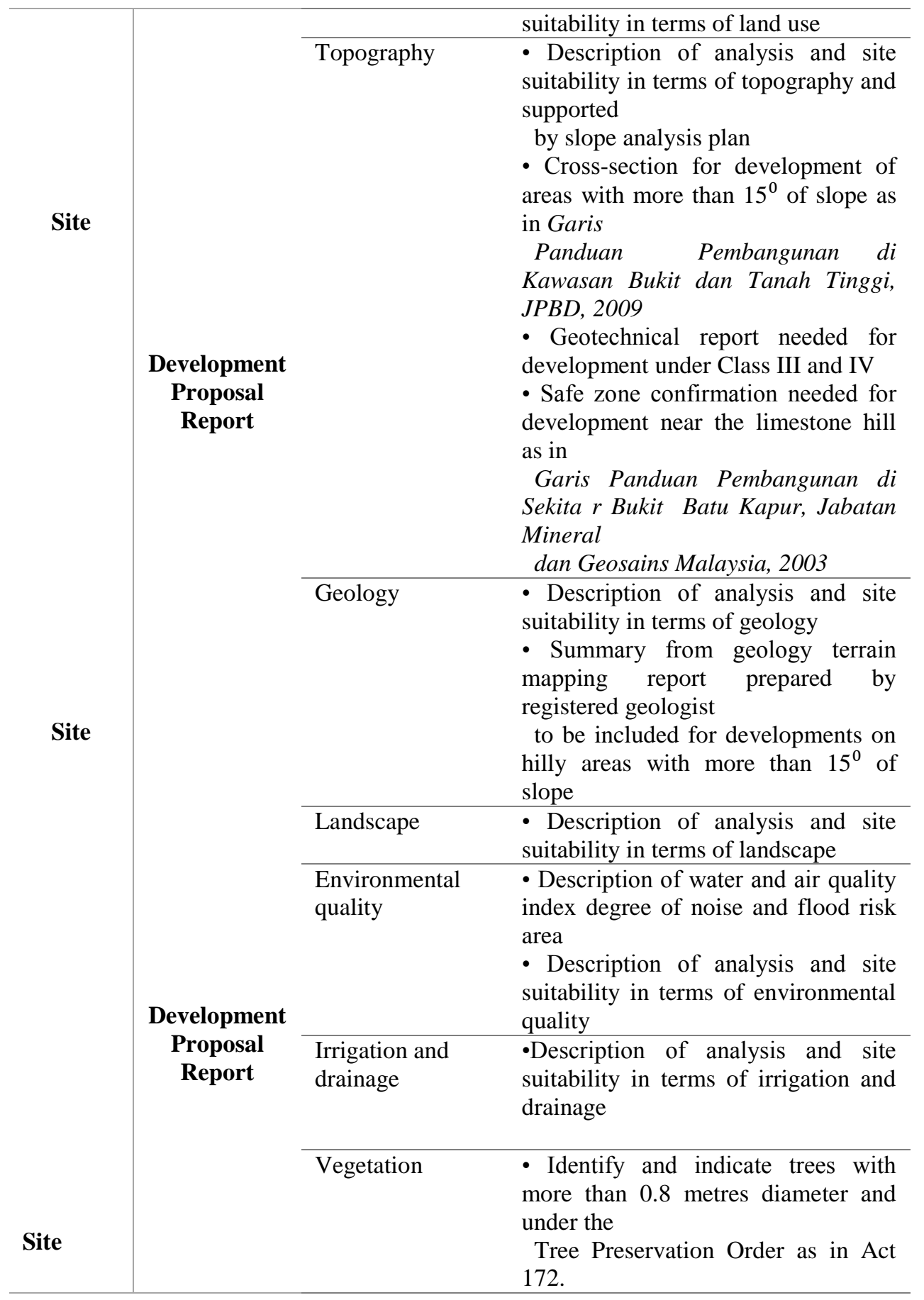


PLANNING MALAYSIA

Journal of the Malaysia Institute of Planners (2014)

\begin{tabular}{|c|c|c|}
\hline \multirow{6}{*}{$\begin{array}{l}\text { Development } \\
\text { Proposal } \\
\text { Report }\end{array}$} & Building & $\begin{array}{l}\text { - Suitability of new development with } \\
\text { existing buildings need to be } \\
\text { considered } \\
\text { and explained } \\
\text { - Summary from Heritage Impact } \\
\text { Assessment (HIA) report need to be } \\
\text { included } \\
\text { for new development in heritage site } \\
\text { area } \\
\text { development to the conservation area } \\
\text { that has been } \\
\text { identified in Local Plan need to be } \\
\text { considered and conservation proposal } \\
\text { need to } \\
\text { be prepared }\end{array}$ \\
\hline & $\begin{array}{l}\text { Infrastructure, } \\
\text { utility and public } \\
\text { facility }\end{array}$ & $\begin{array}{l}\text { - Suitability and carrying capacity } \\
\text { analysis need to be done for } \\
\text { development area } \\
\text { and surrounding area }\end{array}$ \\
\hline & $\begin{array}{l}\text { Development } \\
\text { potential and } \\
\text { constraint }\end{array}$ & $\begin{array}{l}\text { Description of development } \\
\text { potential in terms of physical aspects } \\
\text { including } \\
\text { view and vistas, economy, } \\
\text { environment and social also } \\
\text { development proposal } \\
\text { implication } \\
\text { Description on development } \\
\text { constraint and mitigation and } \\
\text { improvement } \\
\text { measures }\end{array}$ \\
\hline & \multicolumn{2}{|c|}{ Development proposal } \\
\hline & $\begin{array}{l}\text { Analysis of } \\
\text { proposed } \\
\text { development }\end{array}$ & $\begin{array}{l}\text { - Proposed land use analysis in terms } \\
\text { of its suitability and it synchronicity } \\
\text { with } \\
\begin{aligned} & \text { Local Plan from these aspects: } \\
&-\quad \text { Land use zoning } \\
&-\quad \text { Density } \\
&-\quad \text { Height control } \\
&-\quad \text { Plot ratio } \\
&-\quad \text { Plinth area } \\
& \text { - } \text { Development component }\end{aligned}\end{array}$ \\
\hline & $\begin{array}{l}\text { Accessibility and } \\
\text { circulation }\end{array}$ & $\begin{array}{l}\text { Description on proposed road } \\
\text { hierarchy and synchronisation with } \\
\text { existing road }\end{array}$ \\
\hline
\end{tabular}


and committed road to ensure good accessibility

- Traffic Impact Assessment.

- Road Safety Audit (RSA)

$\begin{array}{ll}\text { Irrigation and } & \text { Preliminary Drainage Plan for } \\ \text { drainage } & \text { surrounding area and outside the } \\ \text { development } & \text { construction site to control flood } \\ & \text { before earthwork and construction } \\ & \text { work is } \\ & \text { taking place } \\ & \text { Description on how the water } \\ & \text { features will be conserved if any } \\ & \text { Calculation of capacity of the } \\ & \text { drainage networks and water } \\ & \text { reservoir as in }\end{array}$

reservoir as in

Manual Saliran Mesra Alam (MSMA)

Public facility $\quad$ Proposed public facility must
conform to the planning guidelines

Utility - Location of electric substation must be above the flood level

- Location of water tank must not be at the steep area

- Proposed sewerage system need to conform to guidelines by Suruhanjaya

Pengurusan Air Negara (SPAN)

- Proposed telecommunication system need to conform to guidelines by

Suruhanjaya Komunikasi dan Multimedia Malaysia (SKMM)

Implementation - Measures to protect and improve steps the environment physically

- Measures to protect the natural topography

-Measures to improve in terms of landscape

- Measures to conserve and plant vegetation

- Measures to minimise impact to the infrastructure, utility and existing facilities on site and surrounding area 
PLANNING MALAYSIA

Journal of the Malaysia Institute of Planners (2014)

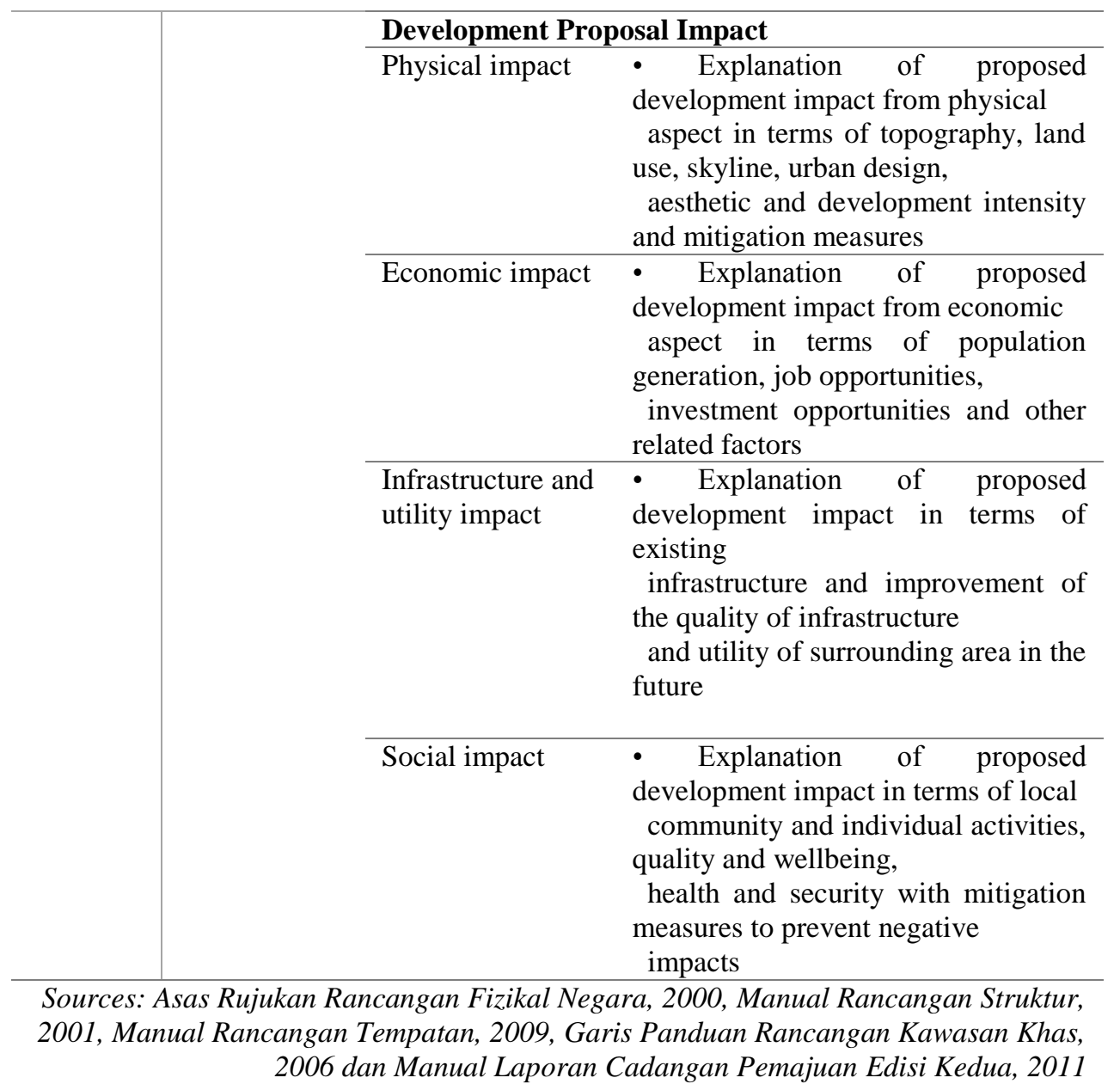

From Table 10, we can see there are efforts to adopt disaster risk reduction agendas in each development plans and document at different planning level. The elements of disaster risk reduction have been set out in every planning sector in each development plans whether in the physical, economic or social aspect. Urban planners should incorporate the disaster risk reduction agendas at the very early stage of any development. 
Intan Afida Mohamad Amin \& Halimaton Saadiah Hashim

Disaster Risk Reduction in Malaysian Urban Planning

The development plans and document prepared at various planning level are important as a guide for development of respective areas. Even though there are disaster risk reductions agendas adopted in the guidelines and manuals, it can be seen that it has been set out generally for each planning sector with a little explanation and a few detail information on how that particular disaster risk reduction agendas need to be addressed and considered by urban planners in their urban planning practices. Every guidelines and manuals need to be very detail and rich with disaster risk reduction information to ensure every development planned by the urban planners in the future will have high level of resiliency and can minimize the vulnerability of people towards disaster risks.

\section{CONCLUSION}

As the conclusion, there are still plenty of rooms for improvement in mainstreaming disaster risk reduction agenda in development plans and document at various planning level such as in terms of availability of complete guidelines and manuals as a reference for urban planners in conducting their urban planning activities in the future. The guidelines and manuals need to be as detail as possible in terms of information related to the disaster risk reduction to ensure urban planners are provided with good and complete references for their daily urban planning practices.

Each development plans and document prepared at all planning level in Malaysia will complement each other in terms of the implementation of disaster risk reduction efforts. Disaster risk reduction agendas set out in the Development Proposal Report will determine the success of disaster risk reduction agendas in the Special Area Plan, Local Plan, State Structure Plan and National Physical Plan. The continuous efforts from the urban planners to mainstreaming disaster risk reduction in their respective practices will help enhancing Malaysian urban planning practices in the future. 
Intan Afida Mohamad Amin \& Halimaton Saadiah Hashim

Disaster Risk Reduction in Malaysian Urban Planning

\section{REFERENCES}

Alarslan, E. (2008). Arising risks in urban settlements: How can urban settlements be made disaster resilient in light of increasingly devastating natural disasters over the last decade?.International Journal of Urban Sciences, 12:1, 49-60.

Benson, C. and Twigg, J. (2007). Tools for Mainstreaming Disaster Risk Reduction: Guidance Notes for Development Organisations. Geneva: ProVention Consortium.

Berke, P. and Smith, G. 2009. Hazard mitigation, planning and disaster resiliency: Challenges and strategic choices for the 21st century. In Sustainable development and disaster resiliency (eds). The Netherlands: IOS Press.

Berke, P. and Stevens, M. (2008). Integrating hazard mitigation into new urban and conventional development. Journal of Planning Education and Research. 28, 441-455.

Bosher, L.and Dainty A. (2011). Disaster risk reduction and 'built-in' resilience: towards overarching principles for construction practice. Disasters, 35, 1-18.

Bosher. (2008). Hazards and the Built Environment Attaining Built-in Resilience. New York: Routledge.

Bosher et al. (2008). A proactive multi stakeholder approach to attaining resilience in the UK Building Resilience: Achieving Effective Post-Disaster Reconstruction (i-Rec 2008).

Bosher et al. (2007). Built-in resilience to disasters: a pre-emptive approach. Engineering, Construction and Architectural Management, 14, 434-446.

Burby, R.J and French, S.P. (1981). Coping with floods: The land use management paradox. Journal of American Planning Association, 47, 289-300.

Centre for Research on the Epidemiology of Disasters Website. Result for Country Profile.[Online]. Available at: http://www.emdat.be/result-country-profile [Assessed 26 February 2014]

Department for International Development. (2012). Multi Hazard Disaster Risk Assessment (v2). United Kingdom: Department for International Development.

Department of Irrigation and Drainage of Malaysia. (2009). DID Manual Volume 1: Flood Management. Malaysia: Kuala Lumpur.

El-Masri, S. And Tipple, G. (2002). Natural disaster mitigation and sustainability: The case of developing countries. International Planning Studies, 7, 157-175.

Esteban et al. (2011). Current mitigation practices in the EU. In Inside Risk: A Strategy for Sustainable Risk Mitigation. Milan: Springer-Verlag.

Haigh, R. and Amaratunga, D. (2010). An integrative review of the built environment discipline's role in the development of society's resilience to disasters. International Journal of Disaster Resilience in the Built Environment, 1, 11-24.

Hamelin, J.P and Hauke, B. (2005). Focus areas: Quality of Life: Towards a Sustainable Built Environment. Paris: European Construction Technology Platform.

International Federation of Red Cross and Red Crescent Societies. (2006). World Disasters Report: Living and Dying in the Shadows. Geneva: International Federation of Red Cross and Red Crescent Societies.

Jabatan Perancangan Bandar dan Desa Semenanjung Malaysia. (2011). Manual Laporan Cadangan Pemajuan Edisi Kedua. Kuala Lumpur.

Jabatan Perancangan Bandar dan Desa Semenanjung Malaysia. (2009). Manual Rancangan Tempatan. Kuala Lumpur.

Jabatan Perancangan Bandar dan Desa Semenanjung Malaysia. (2008). Monograf Geo Bencana dalam Perancangan Guna Tanah. Putrajaya: Kementerian Perumahan dan Kerajaan Tempatan.

Jabatan Perancangan Bandar dan Desa Semenanjung Malaysia. (2006). Garis Panduan Rancangan Kawasan Khas. Kuala Lumpur.

(C) 2014 by MIP 
Faizah Ahmad, Ibrahim Mohd., Syra Lawrance Maidin, Rosilawati Zainol \& Norzailawati Mohd Noor Malaysian Development Plan System: Issues and Problems, One Decade after its Reform (2001-2011)

Jabatan Perancangan Bandar dan Desa Semenanjung Malaysia. (2001). Manual Rancangan Struktur. Kuala Lumpur.

Jabatan Perancangan Bandar dan Desa Semenanjung Malaysia. (2000). Asas Rujukan Rancangan Fizikal Negara. Kuala Lumpur.

Jianping Yan. (2010). 'Disaster Risk Assessment: Understanding the Process'. Paper presented at Training Workshop on Drought Risk Assessment for the Agriculture Sector, 20-24 September, Ljubljana, Slovenia.

Jieh-Jiuh Wang. (2012). Integrated model combined land-use planning and disaster management: the structure, context and contents. Disaster Prevention and Management, 21, 110-123.

Jones et al. (2009). The Built Environment Professions in Disaster Risk Reduction and Response. A guide for humanitarian agencies. United Kingdom: MLC Press, University of Westminster.

McEntire, D. A. (2001). Triggering agents, vulnerabilities and disaster reduction: Towards a holistic paradigm. Disaster Prevention and Management, 10, 189-196.

Mileti,D.S. (2002). Sustainability and hazard. International Journal of Mass Emergencies and Disasters, 21(2), 135-138.

Mohamed Jamil Ahmad. (2008). Management of geohazards through spatial planning. Paper presented at Second National conference on Extreme Weather and Climate Change Understanding Science and Risk Reduction, 14-15 October 2008, Putrajaya International Convention Centre, Putrajaya.

Montoya, L. (2004). 'Book review of natural disasters and development in a globalizing world; Habitat International, 28, 499-500.

National Security Council. (2011). Brief Note on the Roles of The National Security Council, Prime Minister;s department as National Disaster Management Organization (NDMO). Malaysia: Disaster Management Division, National Security Council.

Nolon, J.R. (2006). Disaster mitigation through land use strategies. Pace Environmental Law Review, 23, 959-986.

Ofori, G. (2008). Construction in developing nations: towards increased resilience to disasters. In Hazards and the Built Environment, Bosher et al., eds. New York: Routledge. 39-60.

Pelling, M. (2011). The vulnerability of cities to disasters and climate change: A conceptual framework in coping with global environment. Berlin: Springer-Verlag.

Pelling, M. (2006). Measuring Urban Vulnerability to Natural Disaster Risk: Benchmarks for Sustainability. Open House International.

Powell, L.J. (2009). Urbanization, environmental planning and management: A challenge for Jamaica. Journal of the Malaysian Institute of Planners. 7, 1-23.

UNDP. (2010). Disaster Risk Assessment. New York: Bureau for Crisis Prevention and Recovery, United Nations for Development Programme.

UNDP. (2004). A Global Report: Reducing Disaster Risk A Challenge for Development. New York: Bureau for Crisis Prevention and Recovery, United Nations for Development Programme.

UNHSP Website. Vulnerability Reduction and Disaster Mitigation. [Online].Available:http://www.unhsp.org/content.asp?typeid=19\&catid=286\&cid=866\&a ctiveid $=867$. [Accessed 25 February 2014].

UNISDR. (2005). Hyogo Framework of Action 2005-2015. Geneva: United Nations International Strategy for Disaster Reduction.

UNISDR. (2001). Growing Cities-Growing Threats. UN Habitat: Risk and Disaster Management Unit.

Wamsler, C. (2006). Mainstreaming risk reduction in urban planning and housing: a challenge for international aid organisations. Disasters, 151-177.

Wamsler, C. (2004). Managing urban risk:perceptions of housing and planning as a tool for reducing disaster risk.Global Built Environment Review, 4(2), 11-28. 